$191 \mathrm{LH}$

Draft

Published in Per Andersen, ed., Law and Marriage in Medieval and Early Modern Times (Copenhagen: Djǿf Publishing, 2012), 273-298

\title{
Clandestine Marriage and Parental Consent in John Calvin's Geneva: The Gradual Synthesis of Theology, Statutes, and Case Law
}

\author{
John Witte, Jr. ${ }^{1}$
}

\begin{abstract}
Parental consent to engagement and marriage was one of the staples of early Protestant theology and law. John

Calvin and his Genevan colleague declared parental consent, like individual consent, to be indispensable to the validity of a minor's engagement. The Geneva Consistory inquired closely into the engagements of minors, and routinely dissolved them if their parents dissented. Not only the couple themselves, but also a parent, guardian, witness, or notary to an engagement contract could be punished if they failed to get the necessary consent from both sets of parents. But Calvin ultimately rejected the law of some Protestant communities that allowed parents to annul their children's clandestine marriages as well, declaring, fearing the dangers of parental tyranny and the costs of marital breakup to the couple and their children. He addressed these issues at length in his writings and sermons, and applied these teachings in the detailed work of the Genevan Consistory.
\end{abstract}

Keywords: marriage, secret marriage, mutual consent, parental consent, impediments, annulment, Geneva, John Calvin, consistory, secret marriages, weddings

${ }^{1}$ This article represents work in progress on a multi-volume project with Robert M. Kingdon, Sex, Marriage and Family in John Calvin's Geneva published by Wm. B. Eerdmans Publishing Company. The first volume, subtitled Courtship, Engagement and Marriage (2005) is in print; the second volume, subtitled The Christian Household, will soon go to press. I wish to thank the late Professor Kingdon and Dr. Thomas A. Lambert for their expert commentary and criticisms, and Mr. M. Wallace McDonald for his diligent research and excellent translations of the Consistory cases in the Genevan archives sampled in the third section of this article.

I shall be using the following standard abbreviations throughout: $\mathrm{CO}$ - Ioannis Calivini opera quae supersunt omnia, ed. W. Baum, E. Cunitz, and E. Reuss, 59 vols., Corpus Reformatorum series, vols. 29-87

(Brunswick, 1863-1900); R. Consist. -- Robert M. Kingdon et al. eds. Registres du Consistoire de Genève au Temps de Calvin, 21 vols. (Geneva: 1996- ); R. Conseil -- Les Registres du Conseil de Genève, ed. Emile Rivoire and Victor van Berchem, 13 vols. (Geneva: 1900-1940) 
John Calvin (1509-1564), the Protestant Reformer of Geneva, transformed the Western theology and law of sex, marriage, and family life. Building on a generation of Protestant reforms elsewhere in northern Europe, Calvin constructed a comprehensive new theology and jurisprudence that made marital formation and dissolution, children's nurture and welfare, family cohesion and support, and sexual sin and crime essential concerns for both church and state. Working with other jurists and theologians, Calvin drew the Consistory and Council of Geneva into a creative new alliance to govern sex, marriage, and family life in the city. Together, these authorities outlawed monasticism and mandatory clerical celibacy, and encouraged marriage for all fit adults. They set clear guidelines for courtship and engagement. They mandated parental consent, peer witness, church consecration, and state registration for valid marriage formation. They radically reconfigured weddings and wedding feasts. They reformed marital property and inheritance, marital consent and impediments. They created new rights and duties for wives within the bedroom and for children within the household. They streamlined the grounds and procedures for annulment. They introduced fault-based divorce for both husbands and wives on grounds of adultery and desertion. They encouraged the remarriage of divorcées and widow(er)s. They punished rape, fornication, prostitution, sodomy, and other sexual felonies with startling new severity. They put firm new restrictions on dancing, sumptuousness, ribaldry, and obscenity. They put new stock in catechesis and education, and created new schools, curricula, and teaching aids. They provided new sanctuary to illegitimate, abandoned, and abused children. They created new protections for abused wives and impoverished widows. Many of these reforms of sixteenth-century Geneva were echoed and elaborated in numerous Reformed communities, on both sides of the Atlantic, and a good number of these reforms found their way into our modern civil law and common law traditions. ${ }^{2}$

This chapter analyzes a small but important part of Calvin's reformation, namely, the doctrine of parental consent to their child's engagement and marriage. Parental consent was one of the bright flashpoints of confessional dispute between Protestants and Catholics in the Reformation era. In the first third of the sixteenth century, Protestant leaders like Martin Luther, Martin Bucer, Ulrich Zwingli, and others had championed mandatory parental consent as their biblical answer to the late medieval toleration of 'clandestine' ${ }^{3}$ engagements and marriages. And Protestant magistrates soon instituted

\footnotetext{
2 This is the thesis of Witte and Kingdon, Sex, Marriage and Family in John Calvin's Geneva.

${ }^{3}$ In Calvin's Geneva, the phrase 'clandestine marriage' generally meant marriages contracted without parental consent (and occasionally also without two witnesses). According to some recent studies, 'clandestine marriage' had a second meaning in the day: marriages between parties who married despite an absolute impediment (such as incest or precontract) that they knew but kept clandestine. Some case studies in France and Germany suggest that the second type of clandestine marriage was heavily litigated in late medieval church courts. See Klaus M. Linder, Courtship and the Courts: Marriage and Law in Southern Germany, 1350-1550 (Th.D. Diss. Harvard, 1988), 126ff.; Beatrice Gottlieb, 'The Meaning of Clandestine Marriage,' in Family and Sexuality in French History, ed. Robert Wheaton and Tamara K. Hareven (Philadelphia: 1980), 53; Reinhard Lettmann, Die Diskussion über die klandestinen Ehen und die Einführung einer zur Gültigkeit verpflichtenden Eheschliessung auf dem Konzil von Trent (Münster: 1967). It was the first type of clandestine marriage that Calvin and his colleagues had in mind and that the
} 
new marriage ordinances with a firm parental consent requirement built into their marital formation rules. ${ }^{4}$ In 1563, the Council of Trent instituted similar requirements into the canon law of the Catholic Church.

Calvin and his Genevan colleagues ultimately carved out something of a via media between late medieval Catholic and the early Protestant teachings on parental consent. In Calvin's Geneva, the consent of the couple was indispensable to the validity of both their engagement and their marriage. Without the free and full consent of both the man and the woman, the engagement and marriage contracts were void. The consent of parents (or guardians) was equally indispensable to the validity of a minor child's engagement and marriage. The consent of the father was sufficient; the consent of the mother counted only if the father was absent and other relatives concurred. In the absence of both parents, guardians would give their consent, again with priority for the male voice.

Clandestine engagements were presumptively void in Calvin's Geneva. Either fiancé(e), either set of parents, or even a third party (including a zealous minister or magistrate) could have these engagements annulled and the children punished.

Clandestine marriages, however, were presumptively valid. Neither the couple nor their parents could have their marriages annulled just because they had been contracted without parental consent. Calvin came to this position on the validity of clandestine marriages only reluctantly in later life, aware that he was now closer to medieval Catholic teachings than to the teachings of some other Protestants, and even the Council of Trent.

As with several other topics on marriage and family life, Calvin first set out his legal views on parental consent in some detail in a lengthy Marriage Ordinance that he first drafted for the city of Geneva in 1545 and then revised with a committee in $1546 .{ }^{5}$ Over

Consistory adjudicated. The Consistory did occasionally encounter and punish parties who tried to keep their known impediments clandestine, but they did not apply the term 'clandestine' or 'clandestine marriage' to these instances.

${ }^{4}$ See, among many others, Steven Ozment, When Fathers Ruled: Family Life in Reformation Europe (Cambridge, MA: 1983); id., Ancestors: The Loving Family in Old Europe (Cambridge, MA: 2001); Lawrence Stone, The Family, Sex, and Marriage in England, 1500-1800 (New York: 1979); Robert M. Kingdon, Adultery and Divorce in Calvin's Geneva (Cambridge, MA: 1995); Herman Selderhuis, Marriage and Divorce in the Thought of Martin Bucer, trans. J. Vriend and Lyle D. Bierma (Kirksville, MO: 1999); John Witte, Jr., From Sacrament to Contract: Religion, Marriage, and Law in the Western Tradition (Louisville, KY: 1997).

${ }^{5}$ On August 3, 1545, the Council had commissioned Calvin and the four syndics to prepare a draft marriage ordinance. R. Conseil 40:202v. A draft ordinance was completed on November 5, 1545, presented to the Small Council on November 10, and to 12 representatives of the General Council on November 13. It was commended but not formally approved, and circulated thereafter among ministers and magistrates of Geneva and beyond in slightly varying drafts. CO 10/1:33n. On November 11, 1549, another committee, again led by Calvin, was convened to study existing marriage law and to recommend improvements to the Marriage Ordinance. R. Conseil 44:261v. Calvin presented his report on November 25, but complained on January 20, February 17 and 24, 1550 that still no official position had been taken on the ordinance. R. Conseil 44:273v, 306v, 324v, 329v. On May 1, 1551, Calvin again complained to the Council that the lack of clear guidelines led to much confusion over questions of marriage. It was not until 1561 that it finally 
the next fifteen years, he gradually laid out his theological rationale for these legal views and made modest legal refinements. From the start, the Geneva Consistory and Council, that together governed marriage and family law questions for the city, followed the 1546 Marriage Ordinance to the letter, helping to make the doctrine of parental consent a vital part of the Genevan Reformation.

\section{The 1546 Marriage Ordinance and its Interpretation}

Like the medieval canonists before him, Calvin started with the principle of freedom of marital contract. Marriage, he insisted, depended in its essence on the mutual consent of both the man and the woman. Absent proof of consent by a fit man and a fit woman who had the freedom and capacity to marry, there could be no valid marriage. Calvin defended this principle repeatedly in his commentaries and sermons. 'While all contracts ought to be voluntary, freedom ought to prevail especially in marriage, so that no one may pledge his faith against his will.' ${ }^{6}$ 'God considers that compulsory and forced marriages never come to a good end.... [l]f the husband and the wife are not in mutual agreement and do not love each other, this is a profanation of marriage, and not a marriage at all, properly speaking. For the will is the principal bond. ${ }^{7}$ When a woman wishes to marry, she must thus not "be thrust into it reluctantly or compelled to marry against her will, but left to her own free choice.' 8 'When a man is going to marry and he takes a wife, let him take her of his own free will, knowing that where there is not a true and pure love, there is nothing but disorder, and one can expect no grace from God.'

Also like the medieval canonists, Calvin distinguished between contracts of engagement and contracts of marriage -- or betrothals and espousals as he called them, following the tradition. Engagements were future promises to be married. Marriages were present promises to be married. But, unlike the medieval canonists, Calvin removed the need for the parties to use specific formulaic words: any clear indication of a future or present intent to marry would do. He softened the distinction and shortened the duration between engagements and marriages. He also insisted that the engagement contract be announced through public banns in the church and community and registered with the civil authorities, and that the marriage contract be celebrated in a mandatory church wedding.

The 1546 Marriage Ordinance took pains to ensure the free and full consent of both parties to the engagement and marriage contracts. It required that both sets of

received formal endorsement, now with a few more amendments. See detailed notes in CO 10/1:33 $\mathrm{n}$. The 1545 and 1546 draft is in CO 10/1:33-44 and in Jean-Francois Bergier and Robert M. Kingdon, eds., Registres de la compagnie des pasteurs de Genève au temps de Calvin, 2 vols. (Geneva: 1964), 1:30-38. The final 1561 version is incorporated in Les Ordonnances ecclesiastiques (1561) in CO, 10/1:91-124.

${ }^{6}$ Comm. Josh. 15:14.

7 Serm. Deut. 25:5-12.

${ }^{8}$ Comm. Gen. 24:57.

${ }^{9}$ Serm. Deut. 25:5-12. 
promises be made 'simply' and 'honorably in the fear of God.' ${ }^{10}$ Engagements were to be initiated by 'a sober proposal' from the man, accepted by the woman, and witnessed by at least two persons of 'good reputation.'11 Engagements made in clandestine, qualified with onerous conditions, or procured by coercion were automatically annulled -- and the couple themselves, and any accomplices in their wrongdoing, could face punishment. Engagements procured through trickery or 'surprise,' or made 'frivolously, as when merely touching glasses when drinking together,' could be annulled on petition by either party. ${ }^{12}$ Engagement promises extracted by or from children below the age of consent were presumptively invalid, though children could confirm them upon reaching majority. Engagements involving a newcomer to the city were not valid until the parties produced proof of the newcomer's integrity of character and eligibility for marriage. Absent such proof, the couple had to wait a year before they could marry. ${ }^{13}$

Normally, a Genevan couple, once properly betrothed, had little time to waste. Neither their publicly announced engagement nor the civil registration of their marriage was sufficient to constitute a marriage. A formal church wedding had to follow -- within six weeks of engagement. If the couple procrastinated in their wedding plans, they would be reprimanded by the Consistory; if they persisted, they would be 'sent before the Council so that they may be compelled to celebrate it. ${ }^{14}$

Not only the mutual consent of the parties, but also the consent of their parents was critical to the validity of an engagement and marriage contract. Calvin devoted no less than eight of the first ten articles of his 1546 Marriage Ordinance to the doctrine of parental consent. In the $1545 \mathrm{draft}$, Calvin had seemed so eager to maximize the rights of parental consent that he set the age of majority unusually high: Boys had to be 24 , girls 20 before they could marry without seeking their parents' consent. ${ }^{15}$ The 1546 Marriage Ordinance lowered these ages of majority to 20 and 18 for boys and girls respectively. ${ }^{16}$ This was closer to the Protestant norm but still a bit high, and Calvin still advised that even fully emancipated children 'always be governed by the advice of their fathers.' ${ }^{17}$

The consent of the father was the most critical. The consent of the mother controlled only when the father was absent and no other relatives were present. If other relatives were at hand, the mother's views had to concur with theirs. ${ }^{18}$ In his $1545 \mathrm{draft}$, Calvin had said that, in the absence of the father, the mother needed to have the concurrence only of the 'closest and most important' relatives to consent to a marriage. ${ }^{19}$ He dropped this qualification in the 1546 version. Now it read that the mother's consent

\footnotetext{
10 Item 11, 15, CO 10/1:33ff.

${ }^{11}$ Ibid., item 6.

12 Ibid., item 11

13 Ibid., item 19.

14 lbid., item 16

15 Ibid., item 1

16 Ibid.

17 Ibid., item 10.

18 Ibid., item 2.

19 Ibid.
} 
would count only if and until she had 'consulted one of the relatives if there are any' -without regard for their 'closeness' or 'importance' to the family. In the absence of both parents, guardians would give their consent to a child's engagement and marriage, again with priority for the male voice.

The 1546 Marriage Ordinance made clear that this parental consent was only a supplement to, not a substitute for, the consent of the couple themselves. Parents were prohibited from coercing their children into unwanted engagements, or withholding their consent or payment of dowry until the child chose a partner whom they favored. ${ }^{20}$ Parents were further prevented from forcing youngsters into marriage before they were mature enough to consent to and participate safely in the institution. Children 'observing a modest and reverend spirit,' could refuse to follow their parents' insistence on an unwanted fiancé(e) or a premature engagement. ${ }^{21}$ Other children, confronting a 'negligent or excessively strict' father, could 'have him compelled to give a dowry' in support of a marriage they contracted in spite of him. ${ }^{22}$

The main goal of these provisions was to stamp out the medieval Catholic Church's toleration of what the 1546 Marriage Ordinance called private or 'clandestine promises' (promesse clandestine) -- that is, engagements and marriages contracted without parental consent. ${ }^{23}$

The Ordinance made clear that clandestine engagement promises were 'void' (nulle). ${ }^{24}$ This did not necessarily prevent a clandestinely-engaged couple from going forward with their plans if they received their parents' consent after the fact. But, absent this parental consent, if anyone challenged this engagement because it had been clandestinely contracted, the engagement would be annulled regardless of what the couple wished.

The Ordinance was not so clear about the legal status of clandestine marriage promises -- especially if they had been celebrated, consummated, and yielded children. The crucial statutory language was in item 3 of the 1546 Marriage Ordinance. There, Calvin provided:

If it happens that two young people have contracted marriage by their own action, through folly or recklessness, let them be punished and chastened and such a marriage be dissolved at the request of those who have charge of them. ${ }^{25}$

It was clear from this language that children who entered such clandestine marriages

\footnotetext{
20 lbid., item 8

21 Ibid.

22 lbid., item 7.

${ }^{23}$ Ibid., item 6.

${ }^{24}$ Item 6, CO 10/1:35.

25 Ibid.
} 
would be punished. What was not clear was whether their marriage would be annulled if challenged by their parents.

A plain reading of item 3 suggests that parents could seek annulment of their children's clandestinely 'contracted marriage.' On this reading, while clandestine engagements were automatically 'void,' clandestine marriages were voidable. They would be voided only if and when the children's parents or others 'who have charge of them' brought an action of annulment.

But this reading does not pick up the studied ambiguity in the language of item 3. First, the opening phrase 'two young people' might well have meant only youngsters who were not only below the age of majority but also below the age of consent. Read as such, item 3 was only a statement of the familiar medieval impediment of infancy: that infants and youth may not enter marriage contracts, and when they do, their parents or guardians need to have those promises dissolved or at least postponed until the children reached an age where they could consent or dissent to them. This was, in fact, how that phrase came to be read by the Genevan Consistory in its case law. ${ }^{26}$

Second, the phrase 'contracted marriage' (contracte mariage) could mean either (1) 'contracted to get married in the future'; or (2) 'had already entered a marriage contract.' If the phrase meant the former, then item 3 would mean simply that parents had standing to bring an action to annul their child's clandestine engagement promise. These standing rights of the parents were not specified elsewhere in the statute. It made good sense to stipulate them, particularly since in 1546 when Calvin was drafting the Ordinance the Consistory had no other rules of civil procedure to guide them. ${ }^{27}$ Even if the phrase 'contracted marriage' meant the latter (that the children 'had already entered a marriage contract') the matter was still not resolved. For final validity of the marriage turned on whether the couple had celebrated their marriage in a proper wedding liturgy in the church, not whether they had entered a marriage contract. In Calvin's Geneva, marriage contracts without church weddings were not valid - and those contracted clandestinely or without ceremonies outside of Geneva, would have to be recontracted and celebrated in Geneva in order to be valid. ${ }^{28}$

Third, the two subsequent phrases of item 3 were also ambiguous. The phrase, 'by their own action' (de leur propre mouvement), was separated by a comma from the

\footnotetext{
${ }^{26}$ Witte and Kingdon, Sex, Marriage, and Family, 1:202-19.

${ }^{27}$ What survives of Calvin's efforts to draft a code of civil procedure is in CO 10/1:132-139, analyzed in detail in Josef Bohatec, Calvin und das Recht (Graz: 1934), 209-279. Nothing in the fragmentary draft, however, addresses issues of standing in domestic litigation.

${ }^{28}$ Calvin prepared a detailed marriage liturgy in 1542, which he revised substantially in 1545 , and cosmetically in 1547, 1558, 1559, 1562, and 1563. The 1545 version is in CO 6:203-208. Calvin included legal provisions mandating weddings in his 1541 Ecclesiastical Ordinances (CO 10/1:26) and in his 1546 Marriage Ordinance (CO 10/1:36-37). On the importance of his reforms of marriage liturgy, see Henri Vuilleumier, Histoire de L'Eglise Réformée du pays de Vaud sous le Régime Bernois, 2 vols. (Lausanne: 1927), 1:310-314, 345-348; Bryan D. Spinks, 'The Liturgical Origins and Theology of Calvin's Marriage Rite,' Ecclesia Orans 3 (1986), 195.
} 
next phrase, 'through folly or recklessness' (par follie ou legierté). These two phrases could be read separately. This reading would allow parents to seek annulment of the pending marriage either (1) if it was contracted clandestinely by the couple ('by their own action'); or (2) if the marriage, even if done with the parent's consent, proved to be 'foolish' or 'reckless.' Alternatively, the two phrases could be read interdependently -with the second phrase understood as a qualification of the first. This reading would allow parents to attack a clandestine marriage only if it could be shown that the marriage itself was not only clandestinely contracted ('by their own action') but also was foolish or recklessly entered. This was not so easy a standard to meet. Children who married clandestinely sometimes did so not with recklessness but with elaborate plans to circumvent their parents. And many times their marriages, while not necessarily well advised, were hardly 'foolish,' especially if they were motivated by a desire to get away from overbearing, abusive, or bickering parents.

All this close exegesis might seem like silly legal hairsplitting. But Calvin, who was well trained in law, may well have intended the language of the Ordinance to be a bit open-textured. For the legal status of parental consent and clandestine marriages was a divisive question at the time he was drafting the Ordinance. The first generation of Protestant reformers had required parental consent in an effort to counter the late medieval Catholic practice of tolerating clandestine engagements and marriages. All the leading Protestant reformers allowed parents to annul their children's clandestine engagements. The question that began to divide Protestants sharply after 1540 was whether parents could annul their children's clandestine marriages, too. Some reformers allowed parents to annul their clandestine marriages under any circumstances. Some allowed the same, unless the wife was pregnant or already had children. Some favored continuation of the clandestine marriage. Some insisted on it. The new Protestant laws of the day reflected these disparate views. ${ }^{29}$ This issue became even more divisive in the 1540s and 1550s, when Catholics began accusing Protestants of frivolously dissolving marriages and foolishly catering to the tyranny of parents through their wooden application of the doctrine of parental consent. ${ }^{30}$

Calvin's 1546 Marriage Ordinance did not clearly answer the question whether parents could seek annulment of their children's clandestine marriages. In 1549, Calvin seemed inclined to allow such annulments. The occasion was Calvin's commentary on the Adultero-German Interim (1548), a new imperial law designed to establish the emerging Catholic teachings of the Council of Trent. The Interim insisted that even clandestine marriages were indissoluble because they were sacramental. ${ }^{31}$ Calvin stood

\footnotetext{
${ }^{29}$ See sources and discussion in John Witte, Jr. From Sacrament to Contract: Marriage, Religion, and Law in the Western Tradition, 2d. enl. ed. (Louisville, KY: 2012), chaps. 5-7; Hartwig Dieterich, Die Protestantische Eherecht in Deutschland bis zur Mitte des 17. Jahrhunderts (München: 1970), 123-127. 30 G.H. Joyce, Christian Marriage: An Historical and Doctrinal Study, 2d rev. ed. (London: 1948), 116-124, 416.

${ }^{31}$ Art. XXI.10 of the Adultero-German Interim read: 'Since the father's power justly yields to a union between the parties, you should not listen to those who now insist that contracted betrothals or marriages are dissolved and nullified if there is no consent of the parents. In this, we do not derogate from the obedience that children owe to their parents. But we do not wish parents to abuse their power by impeding
} 
this argument on its head: If a marriage was indissoluble because it was sacramental, shouldn't its sacramental status turn on whether the couple had entered it properly, including their procurement of parental consent:

Of marriages rashly contracted by young persons, let me just say this: It is as easy to deny a word as it is for our moderators to assert one. Who revealed to them that such marriages should be binding?... The dignity of the sacrament, they say, is to be preferred to a parent's right. [But] the more dignity there is in marriage, the more modesty and religion should attend those who enter it. ${ }^{32}$

A decade later, Calvin seemed inclined to regard clandestine marriages as illadvised, but not subject to annulment by parents or anyone else. 'All good men properly disapprove of clandestine marriages which offer an opportunity and even, in fact, an open door to many disgraceful acts,' he wrote in a 1557 consilium. ${ }^{33}$ But even a clandestinely contracted marriage precluded a party from entering a second engagement or marriage -regardless of whether the parents or guardians of the doubly-contracted child now consented to the second match.

By 1560 , Calvin had settled the matter in his mind. Clandestine marriages, once contracted, celebrated, and consummated, could not be annulled absent proof of some other impediment. Neither a dissenting parent nor a distraught husband or wife could seek annulment of the marriage on grounds that it was clandestinely contracted. Indeed, if the marriage was unhappy, it was just what the clandestinely married couple deserved. As Calvin put it in a consilium of 1560 :

When an adolescent has married without his parents' knowledge, he should recognize that he is paying a just penalty for his heedless behavior if his wife is unresponsive to him. He did not offer God and his parents the obedience he owed them, and he should not be surprised if he gets his just reward in the form of his wife's defiance. ${ }^{34}$

This moved Calvin very close to what was the actual bottom line of the medieval canonists: Clandestine marriages were formally prohibited, but when they occurred, the

or dissolving marriages. But, since we think it is good for children not to contract [marriage] without the advice and consent of parents, the preachers should carefully instruct them in their duty.' Translated in John Calvin, Tracts and Treatises in Defense of the Reformed Faith, trans. Henry Beveridge, 3 vols. (Grand Rapids, MI: 1958), 3:220.

32 John Calvin, Vera Christianae Pacificationis et Ecclesiae Reformandae Ratio (1549), CO 7:640.

${ }^{33}$ CO 10/1:242-244, with translation in Calvin's Ecclesiastical Advice, trans. Mary Beaty and Benjamin W. Farley, ed. John H. Leith (Louisville, KY: 1978), 135.

${ }^{34}$ Consilium (Sept. 1, 1560), CO 10/1:252-254. Calvin continued: 'Because it is not disagreement over religion which is tearing the marriage apart, he should fulfill his marital duty as long as he can live with his wife without danger. If greater force and necessity compel him to leave her, he should remain celibate until his wife recovers her senses or gives him cause to divorce her.' Ibid., using translation in Calvin's Ecclesiastical Advice, 147-148. 
marriage should stand and the couple be punished. The medieval canonists used sacramental logic: even clandestine marriages could not be dissolved because they were sacramental. Calvin used prudential logic: Even clandestine marriages could not be dissolved because that catered to parental tyranny, left despoiled virgins vulnerable to spinsterhood, and consigned any children of the union to the bane of bastardy.

\section{Calvin's Theological Reflections}

While Calvin dithered on the issue of whether parents could annul clandestine marriages, he was decisively in favor of the doctrine of parental consent. In his 1546 Commentary on 1 Corinthians 7, published shortly after his Marriage Ordinance, Calvin argued that parental consent to marriage was a 'sacred right' of parents and a 'moral duty' of children. ${ }^{35}$ It enabled parents to guide their children in this final fateful step toward adulthood, and it prevented children from choosing their mates imprudently or impetuously. Particularly when children were still young and vulnerable, it ensured that the marriage was formed by free, full, and mature consent on all sides.

Parental consent, Calvin insisted, does not license 'parental tyranny' over children nor can it substitute for the consent of the child to the marriage. The 'proper rule' of parental consent is that 'children should allow themselves to be governed by their parents, and that they, on the other hand, do not drag their children by force to what is against their inclination, and that they have no other object in view, in the exercise of their authority, than the advantage of their children. ${ }^{36}$ If parents abused their authority, and coerced their children into unwanted engagements or marriages, therefore, such contracts should be annulled. ${ }^{37}$

The doctrine of parental consent to marriage 'originated in the common laws of nature,' Calvin argued in his same 1546 Commentary on 1 Corinthians. ${ }^{38}$ Calvin adverted to these natural law origins of the doctrine several more times in later writings. 'Nature herself dictates that the authority of parents is necessary,' he wrote in 1549. 'This has always been observed by the law of nations and is approved by the testimony of

\footnotetext{
${ }^{35}$ Comm. 1 Cor. 7:36-38.

${ }^{36}$ CO 49: 425-426.

${ }^{37}$ Calvin applied this principle of no parental coercion clearly in an undated consilium (CO 10/1:238-239). The case sent to him for his advice involved a young woman named Marguerite. Her mother had tricked and forced her into marrying a young man named Jean. Jean's brother, aunt, and servant were apparently part of the conspiracy as well. Marguerite was trapped into going through with the wedding. But she was distraught throughout the ceremony and maintained consistently thereafter that she was not married. At least two witnesses testified that she did not say her wedding vows but was silent throughout the ceremony. The notary who recorded the marriage contract testified that the marriage 'was not of God' because Marguerite had not consented to it. Calvin concluded that because 'the girl was forced into it, no foundation for marriage exists.' A properly constituted court should examine Marguerite and her mother closely. If their testimony holds true, the court should annul the marriage, and leave the young woman free to marry another - and punish the mother and her conspirators for coercing the child.

${ }^{38}$ CO 49:425-426.
} 
Scripture.' 39 In 1554, he wrote: '[S]ince marriage forms a principal part of human life, it is right that, in contracting it, children should be subject to their parents, and should obey their counsel. This order [is what] nature prescribes and dictates. ${ }^{40}$ And again: '[l]t is not lawful for the children of a family to contract marriage, except with the consent of parents. And, certainly, natural equity dictates that, in a matter of such importance, children should depend upon the will of the parents. ${ }^{41}$

Surprisingly, Calvin did not ground the doctrine of parental consent to marriage in the Fifth Commandment of the Decalogue: 'Honor thy father and thy mother' (Ex. 20:12; Deut. 5:16) and the amplification of the Commandment by St. Paul (Eph. 6:1-2; Col. 3:20). ${ }^{42}$ Other Protestant Reformers had made the Fifth Commandment a critical source of the right of both fathers and mothers to give their consent to marriage, and the correlative duty of their children to seek the consent of both parents. This was part and product of their elaborate efforts to ground a whole new Protestant legal system in the Ten Commandments. ${ }^{43}$ Calvin did not take this step, at least with respect to the doctrine of parental consent. He might well have been constrained by his insistence in the 1546 Marriage Ordinance that it was the father's, not the mother's, consent that was essential. It would have been hard for him to press the father's superior authority on the strength of a Commandment to 'Honor thy father and thy mother.'

This is not to say that Calvin had a narrow view of the Fifth Commandment or a restricted view of a parent's authority or a child's obedience. In his numerous pages of commentaries, sermons, and catechism entries on the Fifth Commandment, he regularly described parents, especially fathers, as God's vice-regents on earth, in whose title and office God has invested a measure of his being and power, making them 'something divine.' $44 \mathrm{He}$ called upon children to render to their parents forms of 'reverence, obedience, and gratefulness' comparable to what they rendered to God - at least up to the point of violating the Bible and their conscience. ${ }^{45}$

${ }^{39}$ CO 7:639-640.

${ }^{40}$ Comm. Gen. 21:20, CO 23:305-306. In his first edition of the Institutes (1536), Calvin condemned the Catholic canon law for allowing that 'marriages between minors contracted without parental consent should remain firm and valid,' which he considered contrary to 'the laws of all nations and also against the ordinances of Moses.' CO 1:194-195. Calvin repeated this charge almost verbatim in his 1559 Institutes. See John Calvin, Institutes of the Christian Religion [1559], ed. John T. McNeill, trans. Ford Lewis Battles (Philadelphia: 1960), 4.19.37 [hereafter Institutes 1559].

${ }^{41}$ Comm. Gen. 24:1-3, CO 23:329-333.

42 This is treated as the Fourth Commandment in Catholic and Lutheran traditions. On various traditions of numbering and dividing the Ten Commandments, see Bo Ivar Reicke, Die Zehn Worte in Geschichte und Gegenwart (Tübingen: 1973); Paul Grimley Kuntz, The Ten Commandments in History (Grand Rapids, Ml: 2004).

43 John Witte, Jr., Law and Protestantism: The Legal Teachings of the Lutheran Reformation (Cambridge: 2002), 113-115, 125-127, 169-174.

44 Institutes (1559), 2.8.35.

$45 \mathrm{Ibid}$., 2.8.36-38. This caveat, of obeying up to the point of violating God's law, does not appear in his exegesis of the Decalogue in 1536 Institutes, chap. 1 or in Calvin's 1555 Sermons on Deuteronomy 5:16. It might well signal part of Calvin's emerging theory of resistance to tyrannical authority - whether parental, political, or ecclesiastical. On this see John Witte, Jr., The Reformation of Rights: Law, Religion, and Human Rights in Early Modern Calvinism (Cambridge: 2007), chaps. 1-2. 
Calvin gave many examples of the proper obedience that children should render to their parents in conformity with the Decalogue. Included was the duty of children, which Calvin rooted in the Third Commandment, to seek their father's consent to make 'a binding oath,' and the duty of the father, in turn, not to withhold or condition his consent capriciously. ${ }^{46}$ Calvin concluded that, 'if a daughter, while living with her father, has vowed anything without his knowledge, it is of no force.' This was the closest Calvin came to tying the doctrine of parental consent to marriage to the Fifth Commandment. ${ }^{47}$

To ground his doctrine of parental consent, Calvin was more content to point favorably to the examples in the Bible of how some early patriarchs participated in the marriages of their children. For Calvin these were examples, as well as counterexamples, of the natural law in operation. ${ }^{48}$ Calvin saw in the biblical story of Abraham's pursuit of a wife for his son Isaac (Gen. 24:1-67) a particularly good lesson of how and why the natural law of parental consent should operate. ${ }^{49}$ Abraham sought to ensure that his son Isaac, who had come of age, would marry a woman who was both spiritually and physically compatible with him. He sent out his servant to find just the right woman, armed with a clear recitation of the terms of the proposed marriage contract. The servant found a suitable woman in Rebekah. He sought the consent of Rebekah's father, uncle, and mother. He then put down a handsome bride price signified by rings and bracelets. All of this was done, Calvin noted, with full consideration of the consent of the two children, Isaac and Rebekah. The servant made sure that Isaac and Rebekah met together to ensure their compatibility before the contract was sealed.

Particularly notable for Calvin was that Rebekah's father, Bethuel, 'did not exercise tyranny over his daughter, so as to thrust her out reluctantly, or to compel her to marry against her will, but left her to her own free choice. ${ }^{50}$ This stood in marked contrast with many other biblical examples of fathers who contracted or coerced their children into marriage without consideration of their wishes. A good such counterexample was Caleb's crass indifference to his daughter Achsah. ${ }^{51}$ Caleb was one of the spies whom Joshua had sent into the newly promised land of Israel. He was one of the few who had stood up against the majority of the people who had despaired about their ability to conquer Jericho and who wanted to return to Egypt (Num. 13:6, 30; 14:6). While God condemned the people of Israel for their unbelief, God spared Caleb: 'because he has a different spirit and has followed me fully, I will bring him into the land in which he went, and his descendents shall possess it' (Num. 14:24). After the conquest of Jericho, Joshua rewarded Caleb with an ample plot of land. But the land was still occupied (Josh. 14:6, 21:12). Caleb wanted his soldiers to claim the land and to kill its pagan leader. Whoever killed the leader, Caleb promised, could marry his daughter Achsah. Othniel killed the

\footnotetext{
${ }^{46}$ Comm. Harm. Law Num. 30:2-5.

${ }^{47}$ See, e.g., Comm. Harm. Law Ex. 20:12; Serm. Deut. 5:15; Comm. and Serm. Eph. 6:1-4.

${ }^{48}$ See, e.g., Comm. Gen. 21:20 (Hagar and Ishmael); Comm. Gen. 24:1-67 (Abraham and Isaac; Rebekah and mother); Comm. Gen. 34:12 (Schechem and Jacob re: Dinah); Comm. Harm. Law Ex. 21:7-11.

${ }^{49}$ Comm. Gen. 24:1-3, 57.

${ }^{50} \mathrm{CO} 23: 339$.

${ }^{51}$ Comm. Josh. 15:14-17.
} 
leader, and was given Achsah to marry (Josh. 15:16-17). Despite Caleb's noble place in Israelite history, Calvin condemned him roundly: 'How could Caleb presume to bargain concerning his daughter until he knew her wishes,' Calvin wrote incredulously. It was no excuse that Othniel was a valiant warrior. That did not necessarily make him the right husband for Achsah. It also did not matter that Achsah ultimately accepted him as her husband or indeed that Caleb later obliged her by giving the couple a choice plot of land (Josh. 15:18-19). Caleb must have just forgotten to ask Achsah her wishes while 'in the heat of battle,' Calvin concluded. But we have to assume that 'according to the common law the agreement implied the daughter's consent and was only to take effect if it was obtained. 52

Calvin's condemnation of Caleb was of a piece with his condemnation of other fathers and guardians of the Bible who sold their children into slavery or prostitution, or put their daughters on the marriage market as prizes to be sold to the highest bidder. ${ }^{53}$ Even with the power of parental consent, no father was allowed to do this to his daughter. It was the mutual consent both of the husband and the wife, and of the parents and their minor children, that makes the marriage. As Calvin put it:

Although it is the office of parents to settle their daughters in life, they are not permitted to exercise tyrannical power or to assign them to whatever husbands they think fit without consulting them. For while all contracts ought to be voluntary, freedom ought to prevail especially in marriage that no one may pledge his faith against his will. ${ }^{54}$

\section{Consistory Cases}

The Genevan Consistory, on which Calvin sat as Moderator of the Company of Pastors, heard a number of cases raising disputes over parental consent. ${ }^{55}$ The Consistory generally followed the letter of the 1546 Marriage Ordinance. Clandestine engagements involving minor children were presumptively void, unless the parents would later consent. Clandestine marriages were presumptively valid, unless the children could

${ }^{52}$ Comm. Josh. 15:14-17.

${ }^{53}$ See, e.g., Comm. Gen. 29:18-27; Comm. Harm. Law Ex. 21:7-11, Lev. 19:29. But cf. Serm. 1 Sam. 18:22-30; Serm. 2 Sam. 3:14-16 (where Calvin does not criticize fathers for offering their daughters as prizes for valor).

${ }^{54} \mathrm{CO} 25: 529$.

55 In Calvin's day, the Genevan Consistory was something of a hearings court of first instance and a mediator of last resort in cases of sex, marriage, and family life (among many other subjects). It consisted both of local ministers (including Calvin) and members of the city council. The Consistory met once per week for several hours. Parties could petition the Consistory voluntarily or be subpoenaed to appear -often on the recommendation of a local pastor or magistrate. Pleadings were oral. Proceedings were recorded by a notary, which records have been preserved in the register sampled below. Though the Consistory followed the provisions of Calvin's 1546 Marriage Ordinance, it did not have formal legal power, only the power to administer spiritual sanctions. Cases or issues that required legal action or orders were referred to the city council for disposition. In such instances, the Consistory's findings of fact and recommendations of action were probative but not binding on the Council. 
demonstrate highly irregular circumstances. Parents who refused to give their consent were little questioned unless the Consistory suspected foul play. Guardians who refused consent were more closely questioned. Where the views of the fathers and mothers conflicted, the Consistory followed the father. Where the views of mothers and relatives conflicted, the mother prevailed. Parents or guardians who did consent to the engagement were responsible to see that the child was married properly and promptly. Such parents could neither leave the young couple to their own devices, nor seek to withdraw their consent once given.

In most cases, if either party to the engagement was a minor, the Consistory would insist on knowing whether their father or guardian consented -- and would order postponement of the wedding until they were satisfied. In a 1552 case, for example, Louise Loup requested the Consistory to approve her marriage to Nicod des Planches, a minor. ${ }^{56}$ The parties had been engaged before witnesses, and Nicod had given Louise an engagement gift. The Consistory wanted to know whether Nicod's father approved the match. When Nicod reported his father's dissent, the Consistory recommended annulment.

Similarly, in another 1552 case, the Consistory summoned to them two minor couples, Jenon Ramou and Humbert Gallatin as well as Françoise Tournier and Jean Berto. ${ }^{57}$ The Consistory had learned that the two couples had become clandestinely engaged during a party together, each couple apparently serving as witnesses to the other's engagement. When confronted, the couples said this was all done in jest, and they would not want to marry without the consent of the parents. The Consistory called in their parents. The parents of the two girls dissented because of the manner in which the couples had become engaged. The Consistory sent the case to the Council with a recommendation that the engagements be annulled and the two young men punished for seducing the women. The two young women were sent home with a warning to exercise more care the next time.

If both children were minors, it was not enough that only one child had received parental consent. In a 1557 case, for example, Pierre Clerc asked the Consistory to approve the marriage of his minor daughter and Clement de Biffort, also a minor. ${ }^{58}$ The parties had a notarized written engagement contract with mutually favorable terms. Father Pierre was eager to see his daughter get married and urged the Consistory's blessing. Clement, however, had not procured his father's consent. Even though Clement, too, wanted to marry, the Consistory refused to allow the marriage to go forward. Instead, they sent the case to the Council with a recommendation that the notary be punished for notarizing the contract without procuring the consent of one of the two fathers.

The Consistory heard a few cases where fathers and mothers differed over

\footnotetext{
${ }^{56} \mathrm{RC}$ VII, 96, 98.

${ }^{57}$ R. Consist. VII, 96, 98.

${ }^{58}$ R. Consist. XII, 8.
} 
whether to consent to their child's engagement. Each time the Consistory sided with the father. ${ }^{59}$ Typical was the 1547 case of Etienne de Lonnay and a young girl named Maxima. ${ }^{60}$ Maxima's mother had consented to the union, and had signed an engagement contract that Etienne has prepared. When called before the Consistory, however, Maxima testified that she had not consented to the engagement. She reported further that her father, who was away at the time, also did not consent to the marriage. For the Consistory even this hearsay testimony of the father's dissent was enough to trigger an instant annulment. On the Consistory's recommendation, the Council annulled the engagement contract. They also imprisoned the mother both for perjury during trial and for consenting to the engagement, evidently in defiance of her husband's wishes for young Maxima.

The Consistory also occasionally heard cases raising conflicts between mothers and other relatives regarding the engagement of a minor child. In a 1545 case, for example, Girard Reveillet asked the Consistory to approve his forthcoming marriage to a young woman (unnamed in the record). ${ }^{61}$ Girard testified that he had received the consent of his fiancée's uncle in the presence of several of her other relatives, and they had all toasted to confirm the engagement. When questioned, the woman's aunt confirmed this. The young woman, however, testified that she had not consented or toasted to the marriage, and pled with the Consistory to protect her from this unwanted marriage. The Consistory ordered that she be given help in having her mother and brother come to Geneva to testify; her father was evidently not in the picture. The mother appeared the following week, and protested the engagement loudly. A local minister echoed her protest.

Confronted with this conflict between an uncle who consented and a mother who did not consent to the young woman's engagement, the Consistory sent the case to the Council. The Council discovered that Girard was already engaged to someone else in a Catholic territory. Girard returned repeatedly to the Consistory with documents testifying that his first engagement was dissolved, and indeed that his first fiancée had married someone else. The Consistory did not believe him. They became doubly suspicious when they learned that his prior fiancée was a Catholic and that Girard had a reputation for making frivolous promises. Though the record ends here, such a marriage could not have passed muster with both the young woman and her mother protesting the match.

What was left unclear in this case was what the Consistory would have done if both the young woman and her uncle wanted to go forward with the wedding, but the mother did not. The Consistory faced this question squarely in a 1561 case, and they sided with the mother. ${ }^{62}$ Jean Casaux, a minor, had become engaged to Madeleine D’Agnon. Both Jean's brother and his guardian had consented to and helped facilitate

\footnotetext{
${ }^{59}$ See several examples in Cornelia Seeger, Nullité, de mariage divorce et séparation de corps a Genève, au temps de Calvin: Fondements doctrinaux, loi et jurisprudence (Lausanne: 1989) 361ff.

${ }^{60}$ R. Consist. III, 48.

${ }^{61}$ R. Consist. VII, 6, 8v, 11, 49v, 56, 58.

62 R. Consist. XVIII, 135v, 136v-138, 141-141v, 143.
} 
the match. But none of the parties had consulted Jean's mother, who was a Catholic living in a distant town. It turned out that Casaux's mother refused to consent to any engagement until Casaux reached 25, even though she supported his decision to move to Geneva (and presumably also to convert to the Reformed faith). Though the case went down on different grounds, the mother's dissent was enough for the Consistory to annul the engagement, despite Casaux's brother's consent and despite the fact that the mother was a Catholic living well outside Geneva's jurisdiction.

Once parents or guardians had consented to an engagement, they was obliged to see that the parties were properly and promptly married. A Genevan father named Nicolas found this out in $1552 .{ }^{63}$ About a year before, Nicolas had consented to the engagement of his daughter and her fiancé Jaques d'Orléans. Jaques had given the young woman a ring and some property as an engagement gift. The couple had then apparently moved away from Geneva and had put off their wedding. The woman had returned the gifts temporarily until Jaques and her brother could work out more suitable property arrangements. Father Nicolas had apparently not known of, or had at least not objected to, this delay, though it was in clear violation of the 1546 Marriage Ordinance that required the couple to wed within six weeks of their engagement. Since Nicolas still wanted the wedding to go forward, the Consistory ordered him to try to persuade the couple to get on with their wedding plans. If that failed, the Consistory threatened to send them all to the Council to have them punished and the engagement annulled because of the untoward delay.

Once a father or guardian consented to his minor child's engagement, he could not withdraw it. Engagement contracts were serious business in Calvin's Geneva. The Consistory worked hard to ensure that the couples consented to them freely and fully and, if they were minors, that their fathers, mothers, or other guardians consented to them freely and fully as well. But once these engagement contracts were made with free and full consent, neither the couple nor their parents could break them without proof of an impediment. A mere change of heart by any of the parties, or a dispute over property and dowry, were not sufficient grounds to seek annulment.

A Genevan father named Nepveur learned this lesson in $1556 .{ }^{64}$ Nepveur had consented to the engagement of his daughter Jeanne to one Louis Blanchet. The parties had signed a written engagement contract, which specified the property payments that Louis was to make to Nepveur in consideration of the marriage. Shortly thereafter, Louis wanted to move to another town. Jeanne did not want to follow him. The parties agreed to dissolve their engagement by mutual consent. Louis had not delivered his promised payment to the Nepveurs, so father Nepveur decided to withdraw his parental consent to the engagement as well. Louis moved away. The Nepveurs then requested the Consistory for permission for Jeanne to be free to marry another.

The Consistory denied their request. An unconditional engagement contract, they

${ }^{63}$ R. Consist. XII, 8.

${ }^{64}$ R. Consist. XI, 47-47v, XII, 5, 24v-25, 96. 
ruled, could not be broken either by the mutual consent of the couple or by the subsequent withdrawal of parental consent. Moreover, failure of a dowry payment was never a sufficient ground to annul an engagement. Jeanne was still bound by her engagement promise, unless she and her father could prove that Louis had actually deserted her -- desertion being a separate ground for annulment in Geneva.

Similarly in another 1557 case, Jacques Gaudy had consented to his minor daughter Michee's engagement to Nicolas Millet. ${ }^{65}$ Nicolas had promised to deliver an ample engagement gift to father Jacques, when Nicolas returned from a journey. Nicolas was delayed on his return, and then did not tender the full promised payment, causing Jacques to lose some land he had intended to buy with the promised funds. An angry Jacques declared that he was withdrawing his consent to the engagement, and forcibly took his daughter Michee back into his own custody. The Consistory sought to reconcile the parties, explaining to them that his post hoc withdrawal of consent was ineffective. They also reprimanded Nicolas for his delinquency, and ordered him to make the full promised engagement gift. An enraged Jacques, however, said he would refuse the money if tendered because he now believed the young man to be dishonest and wanted him out of the family. After further attempts at reconciliation failed, the Consistory sent the matter to the Council for final disposition, recommending that 'such [engagements to] marriage should not be broken and may not be dissolved, for this would open the door to many others. ${ }^{\prime} 6$

The Consistory reserved the right to second guess the parents, especially when the cases involved young children or the Consistory suspected foul play. In a 1556 case, for example, the Consistory annulled the engagement of a 14-year old young woman Françoise Chastellain who had a debilitating 'hump' that would preclude pregnancy and perhaps even intercourse. ${ }^{67}$ Françoise had evidently consented to the union. Her father had approved the match, and had executed a prenuptial contract with her fiancé and his family. Françoise's father now insisted that the Consistory allow the marriage to go forward. The Consistory decided not only that the woman was too young to be married now, but also that her 'hump' was an absolute impediment to marriage altogether. They annulled the engagement contract, despite the loud protests by the father and fiancé.

In a 1547 case, the Consistory learned that Pierre Mestrazat had become engaged to a ten-year old girl in another town. ${ }^{68}$ Pierre had forced the girl's mother to give her consent to the engagement and allow him to marry the young girl as soon as she came of age. He was now threatening to take the child away to a Catholic territory. All this was 'scandalous,' said the Consistory. They called upon the mother to testify. She confirmed that Pierre had not only threatened her but in fact had 'beaten her villainously' in order to extract her consent to her daughter's engagement. Yet, the mother said she was willing to accept Pierre as her 'son' if he promised to live by the Word of God. The mother was

${ }^{65}$ R. Consist. XII, 45-45v.

${ }^{66}$ R. Consist. 45v.

${ }^{67}$ R. Consist. X, 81.

${ }^{68}$ R. Consist. III, 124, 128. 
not just being pious and charitable. Pierre had evidently signed a contract to pay the costs of the girl's apprenticeship and maintenance in exchange for her later hand in marriage. With no mention in the record of any father, it was likely that this was a single mother doing the best she could to support her child.

Pierre intimated that he would be happy to cancel the engagement contract -- and, by implication, cancel his contract to pay the girl's maintenance and support expenses as well. The Consistory would hear none of it. No doubt still scandalized by the evidence of Pierre's belligerence and his threat to take the girl to a Catholic home, the Consistory insisted on Pierre's full performance of both the engagement contract and the maintenance contract. At the same time, they reserved the girl's right to rescind the engagement contract when she reached the age of consent, which was stipulated as fourteen years of age in this case. The Consistory thereby made Pierre the victim of his own hard bargaining. Pierre had forced the mother into accepting what was, in effect, an installment contract to marry a young virgin. The Consistory converted this into a mandatory child support contract with no guarantee of a bride in return. Indeed, there is no record that Pierre and the girl were ever married upon her reaching the age of consent.

The Consistory ruled similarly in a 1546 case involving the purported marriage of two nine-year olds, Jean Dimier and Nicolarde du Pont. ${ }^{69}$ This 'marriage' was a guardianship arrangement gone utterly amiss. Nicolarde's parents needed to find a place for her to live. They had arranged with Jean's father, Claude, to become a guardian to Nicolarde and to take her into his home. Claude promised to raise her as if she were his own child. Nicolarde's parents gave him funds for Nicolarde's maintenance and support. So far, there was nothing unusual in this arrangement.

But then, inexplicably, the parents had their local minister marry young Nicolarde to young Jean, Claude's son. Even more inexplicably, the minister married the youngsters without reservation. It is hard to know what was motivating the parties to take this unusual step. There was no obvious legal advantage for the couple to be married at this early stage of life. Whatever testamentary advantages might have been gained by the marriage were so remote that this could not have been the motivation. Perhaps Nicolarde's parents thought that Claude's duties of guardianship would be more effectively delivered if his ward Nicolarde were his daughter-in-law rather than just a stranger. Perhaps Claude and his wife wanted to have a daughter, and this arrangement gave them the benefits of effectively adopting a daughter without having to pay for her support. The record does not clearly say.

The record does make clear, however, that Jean's parents thought that the couple was married. Young Nicolarde and Jean were made to sleep together, albeit with father Claude present. But when Nicolarde wet the bed 'under him,' Jean became 'disgusted' with her. Claude and his wife beat Nicolarde severely for her misbehavior and wanted her out of the house.

${ }^{69}$ R. Consist. II, 63. 
A complaint about the minister from Nicolarde's home town brought this whole unusual arrangement to the Geneva Consistory's attention. The Consistory rebuked both sets of parents for their 'monstrous' impropriety. They questioned the children closely. It was obvious that neither Nicolarde nor Jean understood what marriage meant, nor considered themselves to be married. The Consistory thus asked the Council to remove Nicolarde from Claude's home and guardianship and to safeguard her assets. They also asked the Council to declare the marriage contract 'void[able]' and to give the parties the right to confirm or deny the marriage when they reached maturity. Four years later, when the couple came of age, Nicolarde's father, no doubt still chastened by their earlier rebuke, asked the Council whether the couple could marry. Though Jean wanted to marry, Nicolarde dissented because of her earlier mistreatment by Jean's family. The Council thus dissolved the engagement contract and declared that the parties were free to court and marry others.

The Consistory maintained this position on arranged child marriages in later years. This can be seen in a 1557 case of Jaques Rosset and his fiancée Madeleine Lechiere. ${ }^{70}$ The couple had become engaged when both were minors. Claude had apparently used ample gifts of liquor to induce the woman's family to consent to the engagement. Since then, he had fraternized rather freely with Madeleine, much to her family's chagrin. The couple had now reached the age of consent, and the issue was whether they should marry or could they break their engagement with impunity.

Upon learning of the couple's philandering, the Consistory ordered Madeleine to remain in her parents' home while the case was pending. They then ordered that the marriage could proceed only if both sets of parents would come to the Consistory to give their consent to the union. Claude's parents appeared the following week to protest the marriage. The Consistory thus removed the case to the Council, recommending annulment of the engagement, and a permanent prohibition against the parties seeing each other again. The Council ordered the engagement annulled and also imprisoned the couple for their evident fornication.

Had this been a simple case of two youngsters promising marriage, the Consistory could have enforced the letter of the 1546 Marriage Ordinance, namely, that such promises were automatically void. But, it was the purported consent of the girl's parents, even though fraudulently procured, that must have given the Consistory pause.

In the absence of both fathers and mothers, the Consistory would turn to guardians to give their consent to a minor child's wedding. Unless the absent parent's last will and testament or a guardianship agreement stipulated otherwise, the views of paternal uncles and male siblings to the minor child were given priority. In their absence, paternal grandfathers, maternal uncles, and full sisters to the minor child were consulted. Paternal and maternal grandmothers, aunts, and more distant relatives were consulted only as a last resort. The guardian stood in the shoes of the absent parents and was generally free

${ }^{70}$ R. Consist. XII, 13v, 17. 
to consent to or dissent from a minor ward's engagement. ${ }^{71}$

The Consistory would inquire more closely, however, when a guardian neglected or abused his or her authority. An egregious example came in a 1546 case involving a young woman named Mademoiselle Fertz. ${ }^{72}$ Fertz had just lost her parents to the plague. By their last will and testament, her parents had appointed one Pierre Gravier as her guardian. Shortly thereafter, Gravier began sleeping with Fertz. Fertz herself then became infected with the plague. She went to the hospital. There she met another man Pierre Dolen. They, too, began sleeping together. A few days later, Dolen and Fertz became engaged. They kept the matter secret, evidently not wishing to seek the consent of Gravier, Fertz's guardian and first lover. But Dolen gave Fertz an engagement ring to wear. They also broke into Fertz's late parents' home and took some of the money and property they found there. They were imprisoned for their fornication and burglary, but thereafter continued to live together. They then sought to publish their banns of marriage, bringing them again to the attention of the Consistory.

The Consistory summoned Gravier, the guardian, to answer whether he consented to his ward Fertz's marriage. They learned more than they could have expected. Gravier would not approve the marriage. When they pressed him as to why, Gravier admitted to his earlier affair with Fertz. He also testified to his surprise (and no doubt his pique) that Fertz had suddenly become engaged to Dolen. Gravier did not consent to the engagement, but also had done nothing either to care for Fertz or to safeguard the property she had inherited. For the Consistory, this nonfeasance was evidently more than enough to disqualify Gravier from his guardianship, for he faded from the story. ${ }^{73}$

The Consistory focused their attention on Fertz and Dolen. Because the couple had contracted and consummated a clandestine engagement, the Council, on the Consistory's recommendation, annulled their union and punished them severely for their flagrant fornication. Thereafter, they were left free to enter a new engagement contract -provided Fertz's closest relatives were found to give their consent, and provided further that the couple desist from future fornication and cohabitation until their wedding.

\section{Summary and Conclusions}

Parental consent to engagement and marriage was one of the staples of early Protestant theology and law. In the first generation of the Reformation, Martin Luther, Martin Bucer, Ulrich Zwingli, and others had held up the doctrine of parental consent as

\footnotetext{
${ }^{71}$ See examples in Seeger, Nullité, 363-365.

72 R. Consist. II, 86v, 88, 100v.

73 Gravier may well have faced criminal prosecution as well. Even consensual sex between a guardian and ward was a serious crime in Geneva. A 1566 statute that codified the prevailing law provided that a 'guardian or trustee who has fornicated with his ward ... will be proceeded against more severely, even to death if necessary, according to the severity and circumstances of their crimes, at the discretion of the judges.' Emile Rivoire and Victor van Berchem, eds., Les sources du droit du canton de Genève, 4 vols. (Aarau:1927-1935), vol. 3, item no. 1065.
} 
their biblical answer to the late medieval toleration of clandestine engagements and marriages. Unless they had consented to their minor child's unions, parents could seek their annulment. Unless they could prove their parents' abuse, children would be punished for entering such contracts clandestinely. For many reformers, the requirement of parental consent was a moral right and duty anchored in the Fifth Commandment: 'Honor thy father and thy mother.'

Calvin and his colleagues in Geneva accepted much of the prevailing Protestant law of parental consent. They declared parental consent, like individual consent, to be indispensable to the validity of a minor's engagement. The Geneva Consistory inquired closely into the engagements of minors, and routinely dissolved them if their parents dissented. Not only the couple themselves, but also a parent, guardian, witness, or notary to an engagement contract could be punished if they failed to get the necessary consent from both sets of parents. Overbearing or officious parents or guardians would be punished for intruding on the consent of their children or wards. Once parents or guardians had given their consent to their minor children's engagement or marriage, they could not withdraw it. Only proof of another impediment would allow the parents to seek annulment of an engagement or marriage to which they had consented.

Calvin ultimately rejected the law of some Protestant communities that allowed parents to annul their children's clandestine marriages as well. Calvin had left this question unresolved in his 1546 Marriage Ordinance. Initially, he was attracted to conventional Protestant arguments that unless parents could annul their children's clandestine marriages, the doctrine of parental consent would be a mere form of words that guaranteed nothing. Initially, he was also turned off by Catholic arguments that clandestine marriages could not be dissolved because they were sacramental. This, too, for Calvin was a mere form of words that proved nothing: If marriage was an indissoluble sacrament, why should its sacramental status not turn on whether it was properly formed by the couple and approved by their parents.

Calvin ultimately abandoned this early position and resolved that clandestine marriages once consummated could not be dissolved by anyone, including the couple and their parents. His concerns were in part prudential -- about the dangers of parental tyranny and the costs of marital breakup to the couple and their children. His motivations were perhaps also pragmatic. After all, in a small city like Geneva, with its intensely active Consistory and its multi-step public marriage process, it would have been hard for a clandestinely engaged couple to sneak into marriage without discovery by parents or guardians. To be valid, their banns would have to be posted, their certificates publicly registered, their wedding publicly celebrated during a worship service. Throughout this time -- and indeed until the very last step in the marriage liturgy when the pastor called 'if anyone has reason to object to this marriage' -- anyone could protest the match, not least the parents or guardians of the couple. This objection would have automatically halted the process, and put the couple before the Consistory. If they were minors, the Consistory would require them to prove that they had their parents' consent. If they did not have it, their engagement would be annulled. With all these safeguards in place, Calvin must have concluded, it was best to leave clandestinely married couples to lie in 
their marital beds undisturbed. At that point, it was as much the parents' and community's negligence, as their children's delinquency, that the couple had been clandestinely married.

Calvin also accepted much of the prevailing Protestant theology of parental consent - but with two somewhat peculiar new accents. First, Calvin's concerns for daughters and mothers in the process of marital formation stood sharply juxtaposed. On the one hand, Calvin was surprisingly jealous to ensure that girls were as protected from tyrannical parents as boys were in their decision to marry. This was biblically counterintuitive. Both the stories in Genesis and the laws of Moses were filled with examples showing that young women had little voice and few rights in the decision to get married, especially vis-à-vis their fathers. Yet, Calvin showed little patience with any of this. He repeatedly castigated biblical fathers who sold, coerced, or tricked their daughters into marriage. And he lifted up the one example of Bethuel and Rebekah as exemplary of what the natural law teaches about how a father was to care for his daughter's consent.

On the other hand, Calvin was surprisingly churlish about the role of the mother in consenting to her minor's engagement and marriage. Her views counted only if her husband was absent, and then only if they concurred with that of other relatives. Even hearsay testimony of a father's wishes was given priority to a mother's contrary written and oral statements before the Consistory. This strong accent on the father's voice was, of course, typical of the stories in Genesis and the laws of Moses, and indeed of some of the New Testament household codes as well. But why should Calvin stick to the letter and spirit of Bible on the place of a wife, but not on the place of a daughter? Calvin did not say.

This first peculiarity may well be related to a second, namely, Calvin's reliance on natural law, rather than the Fifth Commandment, for the doctrine of parental consent. This was not unprecedented. But both the early Church Fathers and other early Protestants had seen the doctrine of parental consent as part and product of the Commandment: 'Honor thy father and thy mother.' Indeed, the rest of the Commandment seemed to underscore the wisdom of such obedience to parents for the future happiness of children: 'so that your days may be long in the land that the Lord your God gives you.'

For all his robust exegesis of the Decalogue as a source and summary of natural law on many other aspects of life, Calvin did not follow it on the issue of parental consent. Instead, he pointed vaguely and variously to natural law, the law of nations, common equity, and plain common sense to argue for the doctrine. It is hard to know what motivated Calvin in this choice of authority. Perhaps it came down to the simple fact that Calvin had written into his 1546 Marriage Ordinance that it was the consent of the fathers, not the mothers, that counted, and he was sticking to it. It would have been hard to square this provision with the Commandment to '[h]onor thy father and thy mother.' But this was not Calvin's usual style. He was certainly firm and fierce in defending what he wrote. But he would sometimes change his mind, especially when the Bible charted a better way. On this issue, the Bible and the tradition did chart a more egalitarian way. 
Calvin did not follow it. 